\title{
Scientific methodological approach to defining projected indica- tor of financial market infrastructural efficiency
}

\section{Igor Rekunenko}

\author{
Department of Finance, Banking and Insurance, Sumy State University, Ukraine \\ (C) The Author, 2017. This article is published with open access at ARMG Publishing.
}

\begin{abstract}
This research article proposes a scientific methodological approach to calculation of financial market infrastructure index that characterizes a level of infrastructural efficiency. It also describes a staged algorithm of its calculation. It involves indicators that represent both quantity and quality characteristics that precede the development of financial market infrastructure. The calculation of the indicator must be performed as to institutional and private interests of investors. Informative value of this index is aimed at satisfying interests of investors.
\end{abstract}

Keywords: projected indicator, financial market, infrastructure, predictive assessment, infrastructure development index.

JEL Classification: C520, E440, G140.

\section{Introduction}

Effective functioning of financial market is impossible without its extensive and efficient infrastructure. It is an important factor when choosing a market not only for investing, but also for performing certain types or areas of activities that can develop in particular countries.

Herewith, functioning of national infrastructural institutions that provide services at financial market is not effective for a number of specific peculiarities.

The correspondence between quality and amount of financial services and market needs can be achieved by means of tools that allow to manage their efficiency. Among those one can name efficiency evaluation methods that must be used not only for evaluating performance results that provide the development of infrastructural subject of financial market, but primarily the results and assumptions that create conditions for implementation of financial and investment activity.

The enhancement of approaches for evaluation and estimation of infrastructural efficiency, that has been seen as the most important factor that influences the development of financial market infrastructure, presents the current interest for the development of market as it is.

\section{Literature review}

Scientific community has not given enough attention to the research of giving definition to infrastructural efficiency and its predictive assessment. Merely the market's efficiency problems have been studied by the following national and foreign scientists as L. Lopatnikov, Louis Bachelier, M. Beechey, Maurice G. Kendall, Sanford J. Grossman, Joseph E. Stiglitz, Eugene F. Fama, M. Zaporozhets, O. Plastun.

At the same time, the problem of defining the interrelation between the infrastructure efficiency and the level development of the market is not solved in existing approaches for financial market's efficiency evaluation.

\section{Research framework of the study}

The investor can evaluate and predict market's efficiency being guided by the following simple criteria:

$>$ the plurality of buyers and sellers (market liquidity);

$>$ the absence of conditions that impede the implementation of operations;

$>$ the equality of rights and convenience of access to information about the market, market participants and financial assets;

$>$ the relationship between the development of economic system and the changes of stock indices and market price of financial tools issued by enterprises;

$>$ the amount of reliable financial tools for creating a diversified portfolio; 
$>$ the level of technological development of the market;

$>$ the degree of integration with better developed capital markets;

$>$ the attraction of tax and regulatory mode to encourage domestic and foreign investments;

$>$ the quality of state or market regulation $[1,2]$.

Taking into consideration the wide range and multidimensional nature of performance of infrastructure subjects, our task is to create a certain system of indicators and criteria that will give a full description to infrastructural efficiency. Such efficiency will be characterized by suggested financial market infrastructure development index that will be defined by the following postulates.

Since the interests of different subjects of financial market differ from one another, this index must be calculated from the point of interest of investors (both institutional and private). After all, in most cases the information content of this index will be aimed at satisfying those interests of investors.

In order to make an integrated assessment of the financial market infrastructure development, it is necessary to use the method of hierarchy analysis. First of all, one must define the set of indicators $\left(\mathrm{F}_{\mathrm{ij}}\right)$, which will characterize in detail the concept under research, and distribute them into groups $\left(\mathrm{G}_{\mathrm{i}}\right)$. Next, by pairwise comparison of rates in groups and individual groups with each another, based on their relative importance, we determine the weight index that is used to calculate the integral financial market infrastructure development index.

Calculation algorithm includes the following steps.

Step 1. Choosing indicators and their distribution into groups.

The input data is defined by indicators that describe the development of stock market infrastructure. The selected indicators are divided into 3 groups:

1 block - structural indicators $\left(G_{1}\right)$ :

$>$ a share of organized market in monetary terms [in percent] $\left(F_{11}\right)$;

$>$ a number of infrastructural subjects [pcs.] $\left(F_{12}\right)$;

$>$ an existence of a developed system of services and execution of stock exchange transactions (the maximum number of infrastructure subjects involved into the implementation of the agreement) (average number according to selected national financial market) [persons] $\left(F_{13}\right)$;

$>$ an existence of Central Depository $\left(F_{14}\right)$;

$>$ an availability of unified stock exchange system $\left(F_{15}\right)$;

2 block - indicators of market conditions $\left(G_{2}\right)$ :

$>$ a number (average according to national financial market) of emissions of financial tools that are put up for tender [pcs.] $\left(F_{21}\right)$;

$>$ an amount of transactions (the sum) [in local currency] $\left(F_{22}\right)$;

$>$ a quantity (average according to selected national financial market) of funds owners' accounts [million. pcs.] $\left(F_{23}\right)$;

$>$ a quantity (average according to selected national financial market) of accounting operations on the market [pcs.] $\left(F_{24}\right)$;

$>$ a cost (average according to selected national financial market) of agreement (with the agreement of 1 mln. UAH) [in local currency] $\left(F_{25}\right)$;

3 block - indicators of market's infrastructure functioning quality $\left(G_{3}\right)$ :

$>$ a term (average according to selected national financial market) of the execution of stock agreement [hrs.] $\left(F_{31}\right)$

$>$ severity of government regulation $\left(F_{32}\right)$;

$>$ transparency of stock transactions $\left(F_{33}\right)$;

$>$ a value of information (representation, relevance, expediency, adequacy) or information security of infrastructure $\left(F_{34}\right)$;

$>$ a level of confidence in infrastructure $\left(F_{35}\right)$;

$>$ a number of detected violations in infrastructure subjects' performance [pcs.] $\left(F_{36}\right)$;

$>$ a performance of infrastructure subjects' functions by financial intermediaries $\left(F_{37}\right)$. 
Step 2. Normalization of input data.

As most indicators are presented in different units of measurements and are disproportionate to each other, it is necessary to normalize them according to the following formulas:

$>$ let's use the method of natural normalization for stimulant-indicators:

$$
f_{i j}=\frac{F_{i j}-F_{i j \min }}{F_{i j \max }-F_{i j \min }}
$$

where $f_{i j}$ - normalized value of $j$-th indicator of $i$-th block; $F_{i j}$ - value of $j$-th indicator of $i$-th block; $F_{i j m a x}-$ maximum value of $j$-th indicator of $i$-th block; $F_{i j m i n}$ - minimum value of $j$-th indicator of $i$-th block;

$>$ let's use the method of Savidge's normalization for disincentive indicators:

$$
f_{i j}=\frac{F_{i j \max }-F_{i j}}{F_{i j \max }-F_{i j m i n}}
$$

Obtained in both cases, normalized values of $\mathrm{f}_{\mathrm{ij}}$ will be found in the range $[0 ; 1]$.

Next, indicators that need to be normalized are defined (chart 2).

Table 2. Distribution of indicators that require normalization into stimulant-indicators and disincentive indicators

\begin{tabular}{|l|l|}
\hline \multicolumn{1}{|c|}{ Stimulant-indicators } & \multicolumn{1}{c|}{ Disincentive indicators } \\
\hline Number of infrastructure subjects $\left(F_{12}\right)$ & $\begin{array}{l}\text { Number of infrastructural subjects, that take part in agreement } \\
\text { implementation }\left(F_{13}\right)\end{array}$ \\
\hline $\begin{array}{l}\text { Number of emissions of financial tools that are put up for } \\
\text { tender }\left(F_{21}\right)\end{array}$ & Cost of agreement $\left(F_{25}\right)$ \\
\hline Amount of transactions $\left(F_{22}\right)$ & Term of the execution of stock agreement $\left(F_{31}\right)$ \\
\hline Quantity of funds owners' accounts $\left(F_{23}\right)$ & $\begin{array}{l}\text { Number of detected violations in infrastructure subjects' perfor- } \\
\text { mance }\left(F_{36}\right)\end{array}$ \\
\hline Quantity of accounting operations on the market $\left(F_{24}\right)$ & \\
\hline
\end{tabular}

Source: created by author.

As for the other indicators that have no dimension or are expressed in percents, their actual values must be used in further calculations. Therefore:

$f_{i j}=F_{i j}$.

Step 3. Shaping of the matrix of pairwise comparisons and determinig the importance of individual indicators and their groups.

First, we estimate the weight indices for each group of indicators with the help of method of pairwise comparisons. In this regard, the scale of relative importance of certain groups towards the common goal is plotted (Table 3).

Table 3. The scale of relative importance

\begin{tabular}{|l|l|}
\hline \multicolumn{1}{|c|}{ Relative importance } & \multicolumn{1}{|c|}{ Definition } \\
\hline 1 & Groups are equally important \\
\hline 3 & Moderate dominance of one group over the other \\
\hline 5 & Substantive or strong dominance \\
\hline 7 & Critical dominance \\
\hline 9 & Very strong dominance \\
\hline $2,4,6,8$ & Intermediate values between two neighbouring variants \\
\hline Reciprocal values & $\begin{array}{l}\text { If while comparing group A and B, one of the values of } x \text { mentioned above has been obtained, then } \\
\text { while comparing B and A, the reciprocal value } 1 / x \text { must be obtained }\end{array}$ \\
\hline
\end{tabular}

Source: created by author. 
Martix $G$ of size $m \times m$ is given in Table 4 (where $m$ corresponds to the number of defined groups). It accumulates the experts' opinions on mutual priority ranking of peculiar groups.

Table 4. Matrix $G$ of pairwise comparisons of peculiar groups of indicators

\begin{tabular}{|l|c|c|c|}
\hline & Structural indicators $\left(G_{1}\right)$ & $\begin{array}{c}\text { Indicators of market } \\
\text { conditions }\left(G_{2}\right)\end{array}$ & $\begin{array}{c}\text { Indicators of quality of mar- } \\
\text { ket functioning }\left(G_{3}\right)\end{array}$ \\
\hline Structural indicators $\left(G_{1}\right)$ & 1 & 8 & 2 \\
\hline $\begin{array}{l}\text { Indicators of market conditions }\left(G_{2}\right) \\
\begin{array}{l}\text { Indicators of quality of market function- } \\
\text { ing }\left(G_{3}\right)\end{array}\end{array} \quad 1 / 8$ & 1 & $1 / 5$ \\
\hline
\end{tabular}

Therefore, in order to define weight indices, it is necessary to perform calculations of latent roots:

$(G-\lambda E) \times W=0$

where $W$-eigenvector of matrix; $\lambda$ - latent root of matrix $G ; E$ - identity matrix of size $m \times m$.

All calculations are being made with the help of MathCAD program method.

Therefore, it was obtained that maximum latent root of matrix $G \lambda_{\max }=3.006$, and corresponding eigenvector of matrix $W=(0.876 ; 0.102 ; 0.472)$.

Since for the convenience of further calculations it is recommended to consider the total amount of weight indices of all defined groups as 1 , it is necessary to perform normalization of eigenvector values:

$w_{i}=\frac{W_{i}}{\sum_{i} W_{i}}$,

where $w_{i}$ - a value of weight index for $i$-th group.

Therefore, we obtain the following values of weight indices:

$>$ for structural indicators $w_{1}=0.604$;

$>$ for indicators of market conditions $w_{2}=0.070$;

$>$ for indicators of quality of market functioning $w_{3}=0.326$.

Likewise, we plot the matrix of pairwise comparisons for the indicators that form each defined group. Matrix of parwise comparisons for the group $G_{1}$ that contains the structural indicators will look as follows (Table 5).

Table 5. Matrix $G_{1}$ of pairwise comparisons of structural indicators

\begin{tabular}{|l|c|c|c|c|c|}
\hline & $\begin{array}{c}\text { Part of or- } \\
\text { ganized } \\
\text { market in } \\
\text { money } \\
\text { terms }\left(F_{11}\right)\end{array}$ & $\begin{array}{l}\text { The num- } \\
\text { ber of in- } \\
\text { frastruc- } \\
\text { tural sub- } \\
\text { jects }\left(F_{12}\right)\end{array}$ & $\begin{array}{l}\text { Availability of } \\
\text { developed sys- } \\
\text { tem of service } \\
\text { and execution of } \\
\text { stock exchange } \\
\text { transactions }\left(F_{13)}\right.\end{array}$ & $\begin{array}{c}\text { The } \\
\text { existence } \\
\text { of } \\
\text { Central } \\
\text { Deposi- } \\
\text { tory }\left(F_{14}\right)\end{array}$ & $\begin{array}{c}\text { Availabil- } \\
\text { ity of uni- } \\
\text { fied stock } \\
\text { exchange } \\
\text { system } \\
\left(F_{15}\right)\end{array}$ \\
\hline Part of organized market in money terms $\left(F_{11}\right)$ & 1 & 1 & 4 & 6 & 7 \\
\hline The number of infrastructural subjects $\left(F_{12}\right)$ & 1 & 1 & 3 & 5 & 6 \\
\hline $\begin{array}{l}\text { Availability of developed system of service and execu- } \\
\text { tion of stock exchange transactions }\left(F_{13}\right)\end{array}$ & $1 / 4$ & $1 / 3$ & 1 & 3 & 4 \\
\hline The existence of central depository $\left(F_{14}\right)$ & $1 / 6$ & $1 / 5$ & $1 / 3$ & 1 & 1 \\
\hline Availability of unified stock exchange system $\left(F_{15}\right)$ & $1 / 7$ & $1 / 6$ & $1 / 4$ & 1 & 1 \\
\hline
\end{tabular}

Source: own estimations.

Further, maximum latent root and eigenvector of Matrix $G_{1}$ are calculated. $\lambda_{\max }=5.092$, and corresponding eigenvector is $W=(0.719 ; 0.629 ; 0.261 ; 0.104 ; 0.092)$.

The weight indices of every indicator that form a group are marked as $\alpha_{1 j}$. Equation (5) is used for the calculations.

As a result we obtain the following values of weight indices: 
$\alpha_{11}=0.398, \alpha_{12}=0.349, \alpha_{13}=0.145, \alpha_{14}=0.058, \alpha_{15}=0.051$.

In Table 6 we plot matrix $G_{2}$ of pairwise comparisons of indicators of the second group.

Table 6. Matrix $G_{2}$ of pairwise comparisons of indicators of market conditions

\begin{tabular}{|c|c|c|c|c|c|}
\hline & $\begin{array}{l}\text { The number of } \\
\text { emissions of } \\
\text { financial tools } \\
\text { that are put up } \\
\text { for tender } \\
\left(F_{21}\right)\end{array}$ & $\begin{array}{l}\text { The } \\
\text { amount } \\
\text { of } \\
\text { trans- } \\
\text { actions } \\
\left(F_{22}\right)\end{array}$ & $\begin{array}{l}\text { The } \\
\text { quantity } \\
\text { of funds } \\
\text { owners' } \\
\text { accounts } \\
\left(F_{23}\right)\end{array}$ & $\begin{array}{l}\text { The } \\
\text { quantity } \\
\text { of ac- } \\
\text { counting } \\
\text { opera- } \\
\text { tions on } \\
\text { the mar- } \\
\text { ket }\left(F_{24}\right)\end{array}$ & $\begin{array}{l}\text { The } \\
\text { cost of } \\
\text { agree- } \\
\text { ment } \\
\left(F_{25}\right)\end{array}$ \\
\hline $\begin{array}{l}\text { The number of emissions of financial tools that are put up for } \\
\text { tender }\left(F_{21}\right)\end{array}$ & 1 & 3 & 5 & 6 & $1 / 3$ \\
\hline The amount of transactions $\left(F_{22}\right)$ & $1 / 3$ & 1 & 4 & 5 & $1 / 5$ \\
\hline The quantity of funds owners' accounts $\left(F_{23}\right)$ & $1 / 5$ & $1 / 4$ & 1 & 2 & $1 / 6$ \\
\hline The quantity of accounting operations on the market $\left(F_{24}\right)$ & $1 / 6$ & $1 / 5$ & $1 / 2$ & 1 & $1 / 7$ \\
\hline The cost of agreement $\left(F_{25}\right)$ & 3 & 5 & 6 & 7 & 1 \\
\hline
\end{tabular}

Source: own estimations.

Next step defines the maximum latent root and eigenvector of matrix $G_{2}$. We obtain: $\lambda_{\max }=5.307$, and corresponding eigenvector of matrix is $W=(0.449 ; 0.247 ; 0.100 ; 0.069 ; 0.850)$. The weight indices of every indicator that form a group are marked as $\alpha_{2 j}$. Equation 5 is used for the calculations.

As a result we obtain the following values of weight indices:

$\alpha_{21}=0.262, \alpha_{22}=0.144, \alpha_{23}=0.058, \alpha_{24}=0.040, \alpha_{25}=0.496$.

Then matrix $G_{3}$ of pairwise comparisons for the indicators of market's infrastructure functioning quality (Table 7).

Table 7. Matrix $G_{3}$ of pairwise comparisons for the indicators of market's infrastructure functioning quality

\begin{tabular}{|c|c|c|c|c|c|c|c|}
\hline & $\begin{array}{l}\text { Term of the execution of } \\
\text { stock agreement }\left(F_{31}\right)\end{array}$ & $\begin{array}{l}\text { Sever- } \\
\text { ity of } \\
\text { gov- } \\
\text { ern- } \\
\text { ment } \\
\text { regula- } \\
\text { tion } \\
\left(F_{32}\right)\end{array}$ & $\begin{array}{c}\text { Trans- } \\
\text { par- } \\
\text { ency } \\
\text { of } \\
\text { stock } \\
\text { trans- } \\
\text { ac- } \\
\text { tions } \\
\left(F_{33}\right)\end{array}$ & $\begin{array}{l}\text { Value of } \\
\text { infor- } \\
\text { mation or } \\
\text { infor- } \\
\text { mation } \\
\text { security } \\
\text { of infra- } \\
\text { structure } \\
\left(F_{34}\right)\end{array}$ & $\begin{array}{l}\text { The } \\
\text { level } \\
\text { of } \\
\text { confi- } \\
\text { dence } \\
\text { in in- } \\
\text { fra- } \\
\text { struc- } \\
\text { ture } \\
\left(F_{35}\right)\end{array}$ & $\begin{array}{l}\text { The number } \\
\text { of detected } \\
\text { violations in } \\
\text { infrastructure } \\
\text { subjects' per- } \\
\text { formance } \\
\left(F_{36}\right)\end{array}$ & $\begin{array}{l}\text { Performance of } \\
\text { infrastructure } \\
\text { subjects' func- } \\
\text { tions by financial } \\
\text { intermediaries } \\
\left(F_{37}\right)\end{array}$ \\
\hline $\begin{array}{l}\text { Term of the execution of } \\
\text { stock agreement }\left(F_{31}\right)\end{array}$ & 1 & 6 & 5 & 3 & 4 & 6 & 9 \\
\hline $\begin{array}{l}\text { Severity of government } \\
\text { regulation }\left(F_{32}\right)\end{array}$ & $1 / 6$ & 1 & $1 / 2$ & $1 / 6$ & $1 / 4$ & 1 & 3 \\
\hline $\begin{array}{l}\text { Transparency of stock } \\
\text { transactions }\left(F_{33}\right)\end{array}$ & $1 / 5$ & 2 & 1 & $1 / 5$ & $1 / 3$ & 3 & 5 \\
\hline $\begin{array}{l}\text { Value of information or } \\
\text { information security of } \\
\text { infrastructure }\left(F_{34}\right)\end{array}$ & $1 / 3$ & 6 & 5 & 1 & 3 & 6 & 8 \\
\hline $\begin{array}{l}\text { The level of confidence } \\
\text { in infrastructure }\left(F_{35}\right)\end{array}$ & $1 / 4$ & 4 & 3 & $1 / 3$ & 1 & 4 & 6 \\
\hline $\begin{array}{l}\text { The number of detected } \\
\text { violations in infrastruc- } \\
\text { ture subjects' perfor- } \\
\text { mance }\left(F_{36}\right)\end{array}$ & $1 / 6$ & 1 & $1 / 3$ & $1 / 6$ & $1 / 4$ & 1 & 3 \\
\hline $\begin{array}{l}\text { Performance of infra- } \\
\text { structure subjects' func- } \\
\text { tions by financial inter- } \\
\text { mediaries }\left(F_{37}\right)\end{array}$ & $1 / 9$ & $1 / 3$ & $1 / 5$ & $1 / 8$ & $1 / 6$ & $1 / 3$ & 1 \\
\hline
\end{tabular}

Source: own estimations. 
Then, we define the maximum latent root and eigenvector of matrix $G 3$. We obtain: $\lambda_{\max }=7.438$, and corresponding eigenvector of matrix is $W=(0.776 ; 0,092 ; 0.160 ; 0.522 ; 0.286 ; 0.088 ; 0.045)$. The weight indices of every indicator that form a group are marked as $\alpha_{3 j}$. Equation is used for the calculations.

As a result, we obtain the following values of weight indices:

$\alpha_{31}=0.394, \alpha_{32}=0.047, \alpha_{33}=0.081, \alpha_{34}=0.265, \alpha_{35}=0.145, \alpha_{36}=0.045, \alpha_{37}=0.023$.

Step 4. Evaluation of homogeneity of experts' judgments.

The step is performed due to the fact that the quantitative (cardinal) and transitive (serial) homogeneity may be ruined because of the occurrence of severe inconsistencies in experts' judgments.

Homogeneity of judgments is estimated by the index of homogeneity $(I H)$ or ratio of homogeneity $(\mathrm{RH})$ according to expressions:

$I H=\left(\lambda_{\max }-h\right) /(h-1)$,

$R H=I H / M(I H)$,

where $h$ is a number of alternatives that are being compared; $M(I H)$ - an average value (math expectancy) of homogeneity index of accidentally-built matrix of pairwise comparisons.

Since in our case we have compared three groups of indicators, it is obtained for $h=3$ that $M(I H)=0.58$.

Therefore:

$I H=(3.006-3) /(3-1)=0.003$,

$R H=0.003 / 0.58=0.005$.

Ratio of homogeneity for matrixes of pairwise comparisons of indices within groups is calculated in a similar way.

For structural indicators $h=5, M(I H)=1.12$, then:

$I H=(5.092-5) /(5-1)=0.023$,

$R H=0.023 / 1.12=0.020$.

For indicators of market conditions $h=5, M(I H)=1.12$, then:

$I H=(5.307-5) /(5-1)=0.077$,

$\mathrm{RH}=0.077 / 1.12=0.069$.

For indicators of market's infrastructure functioning quality $h=7, M(I O)=1.32$, then:

$I H=(7.438-7) /(7-1)=0.073$,

$\mathrm{RH}=0.073 / 1.32=0,055$.

When for the matrix of pairwise comparisons the ratio of homogeneity $R H>0.1$, it indicates the presence of significant violations of logical reasoning made by the expert while building the matrix and the need to review the data used to build the matrix in order to improve its homogeneity.

As we see, the homogeneity ratio lies within acceptable limits for all four matrixes $(R H \leq 0.1)$, so, we will make the next step.

Step 5. Forming the financial market infrastructure development index.

The calculation for the integrated index of financial market infrastructure development is performed by the following formula:

$$
I F M I D=w_{1} \cdot \sum_{j=1}^{k 1} \alpha_{1 j} \cdot f_{1 j}+w_{2} \cdot \sum_{j=1}^{k 2} \alpha_{2 j} \cdot f_{2 j}+w_{3} \cdot \sum_{j=1}^{k 3} \alpha_{3 j} \cdot f_{3 j},
$$

where $k_{1}, k_{2}, k_{3}$ are a number of indicators that represent each defined group. 
Obtained index values lie within acceptable limits [0;1], herewith, the larger value of index corresponds to the higher level of market infrastructure development.

With the help of quality evaluation we can range the obtained values of integrated market infrastructure development index the following way:

$>[0 ; 0.25]$ - corresponds to rather low level of infrastructure development;

$>(0.25 ; 0.5]$ - corresponds to low level of infrastructure development;

$>(0.5 ; 0.75]$ - corresponds to average (normal) level of infrastructure development;

$>(0.75 ; 1]$ - corresponds to high level of infrastructure development.

\section{Conclusions}

Altogether, in followup of the performed research and with practical calculation of the proposed index, we can receive the results of scenario calculations of the probable development of financial market infrastructure. The developed tools of calculations for the financial market infrastructure development index present interest from the point of view of full understanding of existing processes at the financial market with regard to professional activity and their correspondence to international standards.

\section{References}

1. Beechey, M., Gruen, D., Vick, J. (2000). The Efficient Market Hypothesis: a Survey. Reserve Bank of Australia Research Discussion Paper № 2000-01, 4 p.

2. Fama, E. (1970). Efficient Capital Markets: A Review of Theory and Empirical 17. Work. The Journal of Finance, 25(2), pp. 383-417. 